\title{
AUTOBIOGRAPHY: A VOICE TO THE SUBALTERN
}

Marcela lochem Valente ${ }^{1}$

\begin{abstract}
Due to the diasporic processes and the constant changes in our contemporary world influenced by globalization, the subject previously seen as stable turned into an extremely fragmented one. While living in the world of the "colonizer" this subject has to negotiate between his habits and origins and the new reality in which he is inserted. Although the colonizer attempts to erase the identity of the colonized imposing his own culture and silencing him, Stuart Hall and James Clifford affirm that after the complex encounter between colonizer and colonized there is always modification on both sides. This paper defends the practice of autobiography as a way of giving voice to the colonized people and bringing into public awareness stories that would be hidden, or if not, presented according to the colonizer's point of view, and probably altered.

Key Words: Postcolonial subject, Colonizer vs colonized, Autobiographical practices, Voice to the minority groups.

Resumo: Devido aos processos diaspóricos e as freqüentes mudanças em nosso mundo contemporâneo influenciadas pela globalização, sabemos que 0 sujeito antes tido como estável tornou-se extremamente fragmentado. Ao viver no mundo do "colonizador" esse sujeito tem que aprender a negociar entre seus costumes e origens e o novo mundo no qual está inserido. Embora o objetivo do colonizador seja apagar a identidade do colonizado impondo os seus costumes e silenciando-o, Stuart Hall e James Clifford afirmam que após o contato entre coIonizador e colonizado sempre há modificações em ambas as partes quer queiram, quer não. Este trabalho defende a escrita autobiográfica como uma forma de dar voz ao colonizado e mostrar histórias que seriam ignoradas ou, caso mostradas pelo ponto de vista do colonizador, alteradas.

Palavras-Chave: Sujeito pós-colonial, Relação colonizador/colonizado, Escrita autobiográfica, Voz para minorias.
\end{abstract}

As they established a communal tradition and proposed countertexts to the canon, women of color argued the instrumental role of autobiographical writing in giving voice to formerly silenced subjects (Sidonie Smith \& Julia Watson).

The Western autobiographical canon was constructed from the writings of élite men, was more muted, but has brought about an equal shift of attention, from the chronicles of the privileged to the annals of the labouring poor (Carolyn Steedman).

For a long time, autobiographical practices were seen as a reproduction of the white, male and western stereotype with a fixed identity, excluding all

1 Mestranda em literaturas de Língua Inglesa na Universidade do Estado do Rio de Janeiro (UERJ); bacharel em inglês e literaturas de língua inglesa na mesma universidade; Professora de Literaturas de língua inglesa no curso de letras da Fundação Educacional de Duque de Caxias (FEUDUC). Endereço eletrônico: marcellaiv@ig.com.br. 
other kinds of narratives that did not represent mainstream society. The socalled 'subaltern groups' had no space for a long time, and as Gayatri Chakravorty Spivak stated in her famous essay "Can the Subaltern Speak?", they had definitely no voice. In her essay, Spivak argues that the subaltern, also called the marginal, the oppressed, the Other, has no space, and "[f]or the 'true' subaltern group, whose identity is its difference, there is no unrepresentable subaltern subject that can know and speak itself" (SPIVAK, 1997, p. 27).

Spivak has gone even farther in this issue also tackling the question of the double, or even multiple, oppression faced by the subaltern. She mentions that if the subaltern as male has no voice, the subaltern as female suffers even more for facing more then one single kind of oppression. For Spivak "[i]f, in the context of colonial production, the subaltern has no history and cannot speak, the subaltern as female is even more deeply in shadow" (SPIVAK, 1997, p. 28) facing on the one hand the oppression from the colonizer, and, on the other, from the male subaltern. But it is worthwhile mentioning that even Spivak's position in relation to the subaltern's voice changed later on.

Due to the movements which took place from the $20^{\text {th }}$ century on such as feminism, African-American movements, gay movements, among others in which the purpose was representing minority groups, many patterns and also literary practices were questioned. After these manifestations there was a rethinking of values, and, consequently, a reevaluation of the autobiographical practices. The mainstream centered practice is from this point on defined by some critics as transgressive and fragmented, giving voice even to the subaltern groups. It is also important to be conscious that the fixity and stability that defined the subject so far, really does not exist. As Stuart Hall claims "[t]he subject, previously experienced as having a unified and stable identity, is becoming fragmented; composed, not of a single, but several, sometimes contradictory or unresolved, identities" (HALL, 2005, p. 598). Reaffirming Hall's ideas Sidonie Smith and Julia Watson state that "the old notion of 'self' has been redefined as an illusionary ego construct (a fiction, a phantasm) and displaced by the new concept of 'the subject,' always split, always in the process of constituting itself through its others" (SM ITH; WATSON, 1998, p. 19).

Although we have seen that Spivak defends the voiceless subaltern for some time, Doris Sommer has observed, in her article entitled "Sacred Secrets: A Strategy for Survival", that:

more recently and more reflectively in collaboration with subaltern historians, Spivak has appreciated the "subject-effects" of subaltern eloquence. It is the eloquence of what might be called a genre of "speech-acts" that inverts the relationship between tenor and vehicle (just as Self and Other change places from 
the center to the sidelines) and recognizes the acts of organized resistance as a narrative speech (SOM M ER, 1998, p. 203).

In our contemporary world, due to the developments in the minority studies, also called subaltern studies by some authors, we are conscious that the subaltern does have a voice. There are even some theoreticians such as Homi Bhabha who defend that the subaltern presence is crucial to the selfdefinition of the majority group or mainstream society because they are in a position to subvert the authority of those who have the hegemonic power, and so, they can influence in the redefinition of many concepts and patterns.

In postcolonial literature, it is possible to find several authors who can show the situation of their people and protest against the colonial oppression and violence, and also against the discrimination found in the colonizer's land by their writings. The autobiography can be seen as one of these forms of literary protest. This genre was a possibility for subalterns to denounce the oppression faced and also to bring into public awareness the position of their groups. Autobiography is the construction of a self by means of a textual production, so it is also a way of thinking and felling, giving voice to marginal groups and opportunity for them to defy their role and position in a society full of prejudices and stereotypes, and also to deconstruct the colonial discourse which attempts to erase their identity and give them no voice.

Based in the aforementioned ideas, it is possible to observe that the diasporic movements or the multicultural interactions in general have helped in the changes concerning autobiographies. It was by means of literature, and in many cases specifically autobiographical practices, that many groups could insert themselves into history and society, and as examples of it, it is worthy mentioning women, in a general way, and being even more specific, AfricanAmerican Women.

In the introduction to their book Women, Autobiography, Theory: A Reader, Sidonie Smith and Julia Watson state that "[a]utobiography has been employed by many women writers to write themselves into history" (SM ITH; WATSON, 1998, p. 5). Reaffirming this idea and also helping us to understand it better, we can also mention the work by Tess Cosslett, Celia Lury and Penny Summerfield entitled Feminism and Autobiography: Texts, Theories, M ethods, in which the authors point out that by the writing of autobiographies the marginal subjects are able to express themselves as real subjects and break with the patriarchal and colonial dominance. They argue that "[i]f women have been categorized as 'objects' by patriarchal cultures, women's autobiography gives an opportunity for them to express themselves as 'subjects', with their own selfhood" (COSSLETT; LURY; SUM M ERFIELD, 2000, p. 5-6). 
As the central point of this discussion is the subaltern in a voiced position due to autobiographical practices, it is worthy talking a little about the African-American group. Smith and Watson posit that the autobiographical genre was the one of preference to the African Americans. According to them, this group believed that if they were able to show to the oppressor their capacity of dominating their language, they would also be able to prove that they were as intelligent as the other groups, such as the white colonizers. So, they decided to state the reality of their people through their experience, many times, by means of autobiography. Smith and Watson affirm that "[a]utobiographies by women and people of color introduce stirring narratives of self-discovery that authorize new subjects who claim kinship in a literature of possibility" (SMITH; WATSON, 1998, p. 5). While theorizing this issue, the authors make an interesting reference to Françoise Lionnet's works in which she proposes a theory of métissage in relation to the writing by women of color discussing the hybridity of identity and cultural location:

Françoise Lionnet staked out an intercultural territory of writing by women of
color and proposed a theory of métissage to articulate how marginalized sub-
jects voice their lives. Lionnet argued that as historically silenced subjects, wom-
en and colonized peoples create "braided" texts of many voices that speak their
cultural location dialogically. Métissage, viewing autobiography as a multi-voiced
act, emphasized orality and the irreducible hybridity of identity. In privileging dif-
ference, plurality, and voices, Lionnet asserted that not only new subjects but
new kinds of subjects were emerging, and that "traditional" autobiographies
could be read differently as well (SM ITH; WATSON, 1998, p. 12).

In Lionnet's theory of métissage it is very clear that women of color and colonized people in general do have voice from their texts. She asserts that they are new kinds of subjects, and because of the multicultural contact faced by them, they become hybrids. When talking about hybridity it is impossible not to mention two great theoreticians from the Cultural Studies that are Homi Bhabha and Stuart Hall. According to the authors, these subjects have to assimilate the new culture in which they are inserted, or try to keep their cultural identity and suffer from displacement and constant prejudice creating a "third place" or living in a situation "in-between" the two realities in which they coexist. Because of this process they feel as outsiders, away from home, and so, they need to find a way in which they can express themselves and show this displacement and prejudice that they have to deal with.

In the article "The Narrative Self: Race, Politics, and Culture in Black American Women's Autobiography" Nellie McKay proposes that by using the colonizer's language in order to be heard while writing, the subaltern groups are able to challenge the patterns of the mainstream society and by doing so, 
they are able to transform the silenced race into the voiced one. M cKay states that:

Challenging white hegemony, black autobiographers used narrative to fight their battle against chattel slavery and to engage in the search for political and psychological freedom for all black people [...] [and] Using the white oppressor's language and black cultural tropes (like masking), they transformed the racially inferior, abstract African self of the master's text into the ultimately triumphant black experiential self (M CKAY, 1998, p. 96-97).

According to the author, by expressing their feelings and showing their suffering and displacement, the black autobiographers - and here I would say the autobiographers from the margins, in general - bring into light histories that would not attract the mainstream audiences, and that if it was not by means of literature, histories that would be hidden.

One interesting work to be analyzed while talking about AfricanAmerican autobiographies is the play A Raisin in the Sun by Lorraine Hansberry. Hansberry is a very interesting writer and one of much importance to the African-American literature and history. Her previously mentioned play was produced in Broadway in a time when it was not expected to find black people in the audiences of such a place, and much less on the stages and it is based on her own experiences of displacement, thus being considered, a kind of autobiography.

Lorraine Hansberry was born in 1930 into a middle-class Chicago family who were active proponents of civil rights and tried to protest whenever possible against the segregation laws. They were so certain of their principles that they even decided to send their daughter Lorraine to public schools rather than to private ones as a protest against prejudice and inequality, although they had money enough to support her through private education. When Hansberry was eight years old, her parents bought a house in a white neighborhood in Chicago, and right after moving there they were 'welcomed' one night by a racist mob. The family's home was vandalized in this occasion and Hansberry was injured. Their experience of discrimination there led to a civil rights antisegregation case which her father won before the Illinois Supreme Court. A Raisin in the Sun is loosely based upon this experience, and also a way of protesting against it.

The previously mentioned play shows the struggles of the AfricanAmericans in the USA while in the search for the promises of the American dream. Hansberry shows that although the USA is painted in glowing colors as the land of opportunity, the melting pot and the prosperous place, in this search for happiness and a better life many people can find only prejudice and 
discrimination. In the play, she depicts the story of a black family who also attempted to move into an all-white neighborhood but could find only disillusions. Dealing with themes such as the importance of dreams and the frustration of dreams deferred, the strength of family, the importance of not selling out, the problems of conflicting expectations, selfishness, and the dangers of prejudice and stereotyping, A Raisin in the Sun was Hansberry's greatest success, and it not only brought into public awareness her own experience, but also gave voice to the African-Americans at that moment.

Hansberry was the first black woman to have a play produced on Broadway and not only this; she was also the first afro-descendant and the fifth woman to receive the Best Play of the Year Award from the New York Drama Critics because of this play. She was such a great writer that she had her work not only performed on Broadway, but also turned into a movie released by Columbia Pictures in 1961 with a well-known cast that included actors such as Sidney Poitier; and also, some years later, in 1973, as a musical adapted by Robert Neminoff - her ex-husband - and Charlotte Zaltzberg, with the music composed by Judd Woldin. Raisin won the Tony Award as the best musical and ran on Broadway for nearly three years. To complete the success, another version of the movie was launched in 2004, and in the same year the play has been again on the stages of Broadway, in the Royale Theatre. Last year, the play had the opportunity to be one more time on the stages of Broadway for three months, and this year, it has been adapted to be launched as a made-forTV movie.

Despite its repercussion and importance to the African-American studies I am conscious that, unfortunately, the play I am dealing with in this article is not so widespread. It is well-known just among those concerned with the African-American studies. For this reason, I believe that it is important to present to the reader at least an overview of it in order to make the comments presented in this paper clearer.

A Raisin in the Sun tells us the story of the Youngers, a family who lives in Southside Chicago full of dreams and plans for the insurance they would receive from their deceased father $\mathrm{Mr}$. Younger. Each member of the family has a different plan for the money, what is the cause of many struggles throughout the play. Walter Lee, a black chauffeur, dreams of a better life. He hopes to use his father's life insurance money to open a liquor store; Beneatha, his sister, wants to go to a medical school; their mother, Lena Younger, rejects the liquor business, seeks to put her life as a domestic behind her and provide the means to send her daughter, Beneatha to the medical school. Almost by the end of the play, Lena, also called Mamma - the one responsible 
for the family since her husband's death - decides that the best option for the money would be buying a house for the family, but she does so in a white neighborhood, what leads the family to suffer strong prejudice even before they move.

One of the most impressive scenes in the play is all about prejudice. Just after the house was bought by the family, Mr. Linder, a representative of the all-white neighborhood they were going to move to, goes to the house in which they had been living so far and offers them money not to move. He kindly explains the family that they are not welcomed in that neighborhood because they are different, and they would feel as outsiders there. He explains:

I want you to believe me when I tell you that race prejudice simply doesn't enter
into it. It is a matter of the people of Clybourne Park believing, rightly or wrongly,
as I say, that for the happiness of all concerned that our Negro families are hap-
pier when they live in their own communities (HANSBERRY, 1994, p. 118).

After all, the family decides to take the house refusing the payoff of the white citizens', anticipating the uncompromising policies of the civil rights movement of the 1960s. However, they move to their new house conscious of what they might face in that place.

Mr. Lindner and Clybourne Park represent the white neighborhood in Chicago which Hansberry and her family moved to when she was still a child. And the kind of reception she depicts in the book is very similar to the one her family had in that occasion. In this episode Hansberry is able to show the prejudice that the Other faces in the colonizer's land and the attempt of the hard colonial discourse in posing the different as inferior.

Nellie M cKay points out that "the black female narrative traditions thus evolved from the process of reinventing the self out of the specificities of each black woman's experiences" (M cKAY, 1998, p. 100) and A Raisin in the Sun is exactly that. It is a play based on the author's own experiences showing the cruel reality faced by that specific group at that time, and also inserting them into history, showing something that would be never presented by the colonizer, and if so, surely from a different perspective.

After the short analyses and theoretical points raised in this paper it is possible to understand that "to read women's autobiographical texts is to attend to the historically and culturally specific discourses of identity through which women become speaking subjects" (SMITH; WATSON, 1998, p. 22) and here I propose that not only women, but subaltern groups in a more general way. In their writings they question patterns, challenge the colonial discourse, and struggle against the prejudice they face. To read this kind of literary pro- 
duction is to reaffirm that they do have voice, and in a way, to hear to their voices as well.

Concluding this paper I would like to agree with McKay's words when she states that "Black women's stories need to be heard and accorded their rightful place in the tradition" (MCKAY, 1998, p. 105) and I would also like to propose a rereading of this quotation considering 'Black women's stories' as 'minority groups stories' in a more general sense. The Others' stories need to be heard and accorded their rightful place in the tradition, and we must be conscious that being different is not a synonym of being inferior. 


\section{REFERENCES}

BHABHA, Homi K. Nation and Narration. London: Routledge, 1990.

BHABHA, Homi K. The Location of Culture. London: Routledge, 1994.

BRODZKI, Bella. Mothers, Displacement, and Language. In: SMITH, Sidonie; WATSON, Julia. (Ed.). Women, Autobiography, Theory: A Reader. Madison: University of Wisconsin Press, 1998.

COSSLETT, Tess; LURY, Celia; SUM MERFIELD, Penny. Introduction. In: COSSLETT, Tess; LURY, Celia; SUM MERFIELD, Penny. (Ed.). Feminism and Autobiography: Texts, Theories, methods. London: Routledge, 2000.

EASTON, Alison. Subjects-in-time: Slavery and African-American women's autobiographies. In: COSSLETT, Tess; LURY, Celia; SUM M ERFIELD, Penny. (Ed.). Feminism and Autobiography: Texts, Theories, methods. London: Routledge, 2000.

HALL, Stuart. The question of cultural identity. In: HALL, Stuart. (Ed.) M odernity: An Introduction to M odern Societies. USA: Blackwell Publishing, 2005.

HANSBERRY, L. A Raisin in the Sun. New York: Random House, 1994.

M cKAY, Nellie Y. The Narrative Self: Race, Politics, and Culture in Black American Women's Autobiography. In: SM ITH, Sidonie; WATSON, Julia. (Ed.). Women, Autobiography, Theory: A Reader. Madison: University of Wisconsin Press, 1998.

SALGUEIRO, Maria Aparecida Andrade. Lorraine Hansberry: Afro-América, teatro e autobiografia. In: SALGUEIRO, Maria Aparecida Andrade. (Org.). Feminismos, identidades, e comparativismos: vertentes nas literaturas de língua inglesa. Volume IV. Rio de Janeiro: Europa, 2006.

SM ITH, Sidonie; WATSON, Julia. Introduction: Situating Subjectivity in Women's Autobiographical Practices. In: SM ITH, Sidonie; WATSON, Julia. (Ed.). Women, Autobiography, Theory: A Reader. Madison: University of Wisconsin Press, 1998.

SMITH, Sidonie. Performativity, Autobiographical Practice, Resistance. In: SMITH, Sidonie; WATSON, Julia. (Ed.). Women, Autobiography, Theory: A Reader. Madison: University of Wisconsin Press, 1998.

SOM MER, Doris. Sacred Secrets: A Strategy for Survival. In: SMITH, Sidonie; WATSON, Julia. (Ed.). Women, Autobiography, Theory: A Reader. Madison: University of Wisconsin Press, 1998.

SPIVAK, Gayatri Chakravorty. Can the Subaltern Speak? In: ASHCROFT, Bill et al. (Ed.). The PostColonial Studies Reader. London: Routledge, 1997.

SPIVAK, Gayatri Chakravorty. Diasporas Old and New: women in the transnational world. Textual Practice, n. 10, v. 2, 1996.

STEEDM AN, Carolyn. Enforced narratives: Stories of another self. In: COSSLETT, Tess; LURY, Celia; SUM M ERFIELD, Penny. (Ed.). Feminism and Autobiography: Texts, Theories, methods. London: Routledge, 2000. 
